\title{
ЛІНГВОКОНЦЕПТОЛОГІЯ
}

УДК 811.161.2'42

В. Є. Бєлінська

\section{КОРЕЛЯТИВНІ ПЛОЩИНИ КОНЦЕПТУАЛЬНИХ КАТЕГОРІЙ «ЗЕМЛЯ" Й “КОСМОС» У МОВІ ПОЕЗІЙ П. ПЕРЕБИЙНОСА ТА А. КИЧИНСЬКОГО}

У изй статті визначено кореляцї кониептуальних категорій «земля» $\breve{u}$ «космос» у поетичній мові украйнських митиів П. Перебийноса та А. Кичинського. Проаналізовано особливості використання елементів изх категорій у складі метаборичних конструкцій. Відзначено спільні й відмінні риси означених поетів, зумовлені аналогіями в походженні й мовній картині світу. Зроблено висновок про те, шо головними об'єктами кониептосфери "природа» в поетичній мові П. Перебийноса та А. Кичинського є кониепти-категорії «земля», «степ», «космос», "село», взаємопов'язані в описах ландшафту.

Ключові слова: П. Перебийніс, А. Кичинський, поезія, категорії «земля»

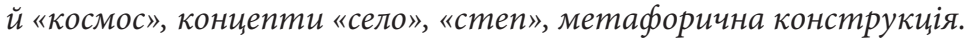

Bielinska V. Correlative Planes of Conceptual Categories "Earth" and "Space" in the Poetry Language of P. Perebyinis and A. Kychynskyi. This article identifies the correlations of the semantic fields "Earth" and "Space" in the language of Ukrainian poets P. Perebyinis and A. Kychynskyi. P. Perebyinis and A. Kychynsky, as traditional representatives of Ukrainian poetry and ethnic language picture of the world $(L P W)$, by origin - peasants, the most representative in the landscape description are the concepts of "steppe" and "village", which in the structural sense can be relevant categories, that combine elements of these natural objects. The peculiarities of the use of elements of these categories in the composition of metaphorical constructions are analyzed. The common and distinctive features of these poets are marked by the analogies in the origin and language picture of the world.

A. Kychynskyi more often uses the image of the Earth as a planet. It is not only a planet, but the location of the father's home, a place where healing herbs grow, with the value of the author's affinity for the object, it also indicates the Earth's status.

Unlike the cosmic status of the planet, the earth in the sense of its surface, marked by P. Perebyinis writing with a small letter, is of conceptual importance to people, since it denotes many vital signs for them such as soil, color, - an agricultural attribute that has family characteristics, concept - an element of the Ukrainian LPW and a temporary sign of life.

P. Perebyinis's metaphorical constructions with the element of the earth indicate that the lyrical hero lives here, his life is connected with the earth. The sense 
of unity with the earth is common to both poets. A. Kichinskyi feels the essence of real life in this.

The conclusion is drawn about the prerogatives of rural subjects in both poets. The main objects of the conceptual sphere "nature" in the poetic language of P. Perebyinis and A. Kychynskyi are defined conceptual categories "earth", "steppe", "space", "village", which are interconnected in the descriptions of the landscape, representing the recipient and donor elements of metaphorical and epithetical constructions. They mainly exhibit anthropomorphic features that manifest the author's poetic intentions.

Key words: P. Perebyinis, A. Kychynskyi, poetry, categories "earth" and "space", concepts "village", "steppe", metaphorical construction.

\section{Вступ}

Розвиток України як незалежної держави передбачає насамперед непорушність національного складника, що наповнює всі сфери суспільного буття - політичну, соціальну, культурну й навіть економічну, як би цього не намагалися уникати представники законодавчої влади. Тож усі проблеми зрештою зводяться до нагальної потреби виявлення етнічної ідентичності в тієї більшості, що зумовила конституційну формулу «національна унітарна держава». Тобто українці мають бути свідомі того, що вони будують власну національну державу з пріоритетною етнічною мовою й дотриманням етнічних традицій.

Один з таких давніх пріоритетів - переважно сільська тематика української літератури, зокрема поезії, що зумовлено й демографічно - сільським походженням поетів, які є етнічно орієнтованими митцями, виявляючи натурфілософське осмислення буття. Тобто їхня концептуальна картина світу (далі - ККС) складається з елементівконцептів «степ», «село», «вода», «ліс» тощо, що в межах поетичного тексту можуть корелювати з антропоморфними, урбаністичними або й «космічними» образами.

Через таку «сільську» орієнтованість поезії українські митці могли розширити концептуальну базу етнічної й індивідуальних ККС, що, за словами А. Загнітка, є логічним процесом - залежним «як від об’єктивних, так і суб'єктивних чинників - інтенцій соціуму чи індивіда» [Загнітко, 2010: 39]. Про це також зазначає багато українських учених, зокрема О. Воробйов (дослідження концептології в Україні), Ю. Арешенков (дослідження поетичного ідіостилю Т. Шевченка), I. Шкоріна (дослідження концептуальної опозиції «місто - село»), О. Юрченко (дослідження концептосхеми природних реалій нижньої 
Наддніпрянщини) та ін.

Сільське походження літераторів апріорі зумовлює своєрідний материнський антропоморфізм, коли образ матері пов'язується з об’єктами природи як реципієнтний або донорський елемент, що творить, за словами А. Мойсієнка, через метафоричні конструкції систему внутрішніх знакових елементів тексту (Мойсієнко, 2008: 12). Поряд $з$ ним (або зіставлювані з ним) домінують концепти «село», «степ», «хата», які й досліджують сучасні вчені в межах авторського ідіостилю. Зокрема Н. Бондар вивчає «село» як базовий концепт української ментальності; Ю. Лебеденко, Т. Свердан й І. Маляр «хату» в українській фразеології; О. Боронь - образ саду в Т. Шевченка; І. Ткаченко - мовний мовний образ степу в поезії Ліни Костенко; М. Шленьова - поетичний образ села в В. Голобородька.

\section{Методи та методики дослідження}

Утім, слід відзначити потребу комплексного аналізу цих «сільських площин» і їхніх мовних репрезентантів у кореляції з елементами категорії «космос» у поезії сучасних українських авторів. Мета цієї статті - дослідження й опис корелятивних площин мовної реалізації концептуальних категорій «земля» й «космос» у поетичній мові А. Кичинського та П. Перебийноса. Для цього потрібно визначити роль елементів означених категорій у побудові метафоричних конструкцій, що їх використовують у ландшафтному описі, за допомогою методів - описового (систематизація й узагальнення фактичного матеріалу), контекстного аналізу (дослідження метафор), функціонального (використання мовних одиниць у реалізації художньої функції), компонентного аналізу (виявлення структурних компонентів семантичного наповнення концепту), компаративного аналізу (зіставлення мови двох поетів).

\section{Результати та дискусії}

У П. Перебийноса й А. Кичинського як традиційних представників української поезії й етнічної ККС, за походженням - селян, найбільш репрезентативними в ландшафтному описі постають концепти «степ» і «село», які можуть у структурному сенсі становити й відповідні категорії, що об’єднують елементи цих природних об’єктів (за словником - «великий безлісий, вкритий трав'янистою рослинністю, рівнинний простір» і «сільська місцевість узагалі» (Великий 
тлумачний словник..., 2001: 1389, 1305)). Психологічно село й степ асоціюються переважно зі спокоєм, й оскільки М. Максюта рисами сільського життя визначає саме спокій - узвичаєність, постійність, усталеність (Максюта, 2003: 110), то ці атрибути історично $є$ архетипними для українців, а їх лексичні маніфестанти (кліматоморфні, фітоморфні, зооморфні) входять до етнічної мовної картини світу.

Означений спокій у П. Перебийноса виявляється в метафорі «цідиться крізь мене тиша польова» (Перебийніс, 2005: 8), де виділене словосполучення позначає безпосереднє сприйняття ліричним героєм тиші польової. Аналогічно природна ознака вологості зіставляється $з$ потом: «росу стираючи з чола» (Перебийніс, 1979: 48) (порівн., роса - сльозина (Перебийніс, 2011: 423)). Недарма серце ліричного героя відпочиває «на долоні степу», а душа «змиває полуду пилюги», коли він іде «через луги» «від станиії до раю» (Перебийніс, 2011: 421, 418). Відповідно до концептуальної опозиції «село - місто» в наведеному вище фрагменті саме іменник станція репрезентує категорію урбаністичних ознак.

Ці елементи А. Кичинський пов’язує також і з концептом «час». Наприклад, у строфі «Там легко від села і неоглядки // біжать у світ ріллею навпрочки, // зав'язуючись вузликом на згадку, // на довгу згадкy, // всі мої стежки» (Кичинський, 1979: 94) виділені елементи репрезентують означені концепти, а слова біжать, неоглядки, навпрошки, на згадку - часову парадигму. Часовий опис може й не включати елементів степу, але в ньому відчувається атмосфера простору, що разом 3 лексемою лісосмуга асоціюється саме зі степом: «Літній день затихне, мов свіча, // віджаріє на вечірнім прузі. // Притулившись до мого плеча, // заночує вітер в тісосмузі» (Кичинський, 1979: 7). Виділені дієслова складають часову послідовність, а дієприслівник притулившись - семантичний контекст спокою (заспокоєності).

П. Перебийніс у межах кореляції елементів категорій «степ» i «село», зокрема їхніх ядерних концептів, маніфестує метафоричні зіставлення з використанням зооморфних і фітоморфних елементів, антропоморфних і топоморфних (атрибути сільського краєвиду). Так, ототожнення села й природи виявляється в порівнянні хати з білою качечкою в поезії «Біла качечка»: «Тітчина хата - // біла качечка над левадою - // пливла собі в день черешневий // і вікнооко позирала на город. // Скучала за тіткою» (Перебийніс, 1990: 60). Подвійність 
метафори полягає в тому, що зіставлення хати й качечки відбувається із залученням антропологічних характеристик. Якщо дієслова пливла, дивилася й позирала можуть бути властиві й качечці, то плакала й скучала властиві саме людині. Також ознаку хати як живого об’єкта репрезентовано прислівником вікнооко, що є похідною формою від авторського епітета (хата вікнооко позирала й плакала вікнооко).

Пріоритетність білого кольору в загальній колористичній палітрі виявляється в поезії А. Кичинського. Так, на відміну від вечірніх, денні ознаки літа передбачають світлову градацію: «де білий день, як полум'я, стоїть, // де сонечко, аж боляче зінииям» (Кичинський, 1979: 24). Виділені світлові елементи позначають загалом білий колір - у його вищому ступені сліпучості, що репрезентована іменниками полум'я й сонечко, а також прислівниковим словосполученням 3 тактильною ознакою аж боляче зінииям.

В опозиційній характеристиці «позитивне - негативне» степ у П. Перебийноса маркований переважно позитивними ознаками, що загалом позначають розквіт, життя природи - рослин («картопля на городі випростує листочки», «кучері гороху у росах шелескочуть», «ліхтариками світять бутони гарбузові») і комах («коник у стременах туркоче до знемоги», «військо мурашине бере свої висоmu») (Перебийніс, 2011: 400). Можна сказати, що це опис природи, яка випромінює вічний спокій: «У кашкеті парубочім сохне сонях. // Дибуляє в хащах літа стрибунець»; «Тут листочок пересохлий // і грибочок з парасолею» (Перебийніс, 2005: 196). Зазначимо, що це опис не власне степу чи лісу (сонях - польова рослина, гриб - лісова) - це комплексні ознаки життя сільської природи.

Схвальні ознаки життя природи переносяться й на площину особистих почуттів, зокрема інтимних. Зокрема, у строфі «Нам свічечкою світить // листочок іван-чаю. // Веселка семицвітом // чоло твоє вінчає» (Перебийніс, 2005: 298) така ситуація виявляється через займенники нам, твоє й віртуальний віночок, що «чоло твоє вінчає». I взагалі поле для ліричного героя є оберегом - він намагається туди повертатися час від часу для підтримки свого душевного стану: «Летів і впав на рідне поле, // що не забуло ще мене, // упав на роси прохололі, // на зріле жито запашне» (Перебийніс, 1990: 39). Це бажання виявляється в послідовності виділених дієслів, а означальні словосполучення рідне поле, роси прохололі, зріле жито запашне репрезентують 
концептуальні атрибути в житті поета. Зрештою він радіє, що поле його не забуло ще, і поки це ще так - доки він буде жити.

В опозиційній характеристиці «динамічне - статичне» А. Кичинський в описі степу частіше виявляє саме динамічність, що маніфестована природними елементами вітру й птахів, які традиційно й асоціюються зі швидкістю. Наприклад, у фрагменті «Де вітер - мов розтоплена латунь, // де бистрі птиці, мов метеорити» (Кичинський, 1979: 24) ці елементи порівнюються з розтопленим металом і космічним тілом, що додає їм експресивності. Зазначимо при тому однорідність порівнюваних об’єктів: птииі й метеорити - конкретні назви, що передбачають певну обмеженість у просторі, а вітер і розтоплена латунь - більш абстрактні, менш обмежені. Тобто порівняння виявляють не лише майстерність поета, але й розсудливість (аналітичність).

Звісно, що опис степу не можливий без залучення його елементів - ентоморфних й орнітоморфних, що беруть участь і у візуальних картинах, і в аудіальних: «В юному сіні // зелен коник шелеснув. // Роса // конюшину та коней купала. // Довгі літа зозуля кувала» (Кичинський, 1979: 17). Також тут наявні фітоелементи сіно, конюшина, що загалом формують часові ознаки ранку (периферійний репрезентант - роса) й літа (ознака - юне сіно).

У поезіях П. Перебийноса категорії «село» й «степ» пересікаються з категорією «космос» через зіставлення сільських атрибутів з елементами неба й космосу. Зокрема, у поезії «Міжзір'я» автор метафорично наближає село до небесної сфери: «Віє вічністю в обличчя. // Ще світанок не дозрів. // У селі неначе ближие // до безмежності, до зір». Безособові дієслова у виділених словосполученнях уже за своєю формою створюють відчуття сільського простору, що є частиною космічного безмежжя, і поет себе зараховує до обох цих площин: «Я засвічена частинка // всіх поєднаних світів» (Перебийніс, 1990: 132).

Зіставлення сільського й небесного простору більш конкретизується поетом у парі «степ - космос». У поезії «Серпнева ніч» П. Перебийніс зіставляє елементи категорії «космос / усесвіт» зі степом, створюючи особистий (самотній) «космічно-степовий простір» з такими компонентами: «зорі незлічимі», «лищ зорі $і$ сяєво соломи», «колосочок чи зірка променем холодним чоло моє лоскоче» (Перебийніс, 1990: 98). 3 них виділяємо елементи метафоричного зіставлення 
земної й небесної сфер: солома - зорі, колосочок - зірка. Також звертаємо увагу на метафору «лежу до Всесвіту очима», що має подвійний контент: безпосереднє споглядання неба лежачи й постійне споглядання й аналіз Всесвіту.

П. Перебийніс висловлює свою творчу концепцію через фразу «А я живу. // Єднаю небо і траву» (Перебийніс, 2005: 18), де виділене словосполучення позначає зв'язок земного з небесним - Села й Космосу. I якщо другий елемент $є$ більшою мірою віртуальним, то та ж таки хата - конкретним: «Але світилася чолом // хатинка за лісами. // Вона гостила нас теплом // і тихо колисала. // I надвечірньої пори // у стінах дерев'яних // по-украӥнському вітри // свистіли солов'ями» (Перебийніс, 2011: 436). Виділені словосполучення наповнені позитивною семантикою, що загалом виявляє характеристики гостинності, затишку й національної концептуальності.

Означені категорії входять до більш загальної просторової сфери «земля», що за семантичною наповненістю дорівнює сфері «світ». На нашу думку, у П. Перебийноса світ має подвійний смисл: по-перше, це місця існування людини, тобто все, що довкола ліричного героя, на що він може здійснювати вплив (тобто планета Земля); по-друге, це всесвіт / космос - необмежені простори й концептуальна категорія. Недарма Д. Павличко відзначає «космічне бачення» поета (Павличко, 2011: 9).

Характеристика довколишнього світу здійснюється поетом через метафори, що є традиційними (стертими), на кшалт «світ його гніmuть» (Перебийніс, 1979: 83), проте автор додає й елементи власного світовідчуття: «світ кипить, міняється щодень» (Перебийніс, 1979: 93), «довічне око світу» (Перебийніс, 1979: 8), часто використовуючи авторські епітети, на кшалт «світ розкутий» (Перебийніс, 1979: 93), чим демонструє різні ознаки світу - різнобічну динамічність (через дієслова гнітить, кипить, міняється), вічність і вільність (через прикметники довічне, розкутий).

В А. Кичинського лексема світ як ядерний елемент макроконцепту «всесвіт» може репрезентувати й мікросвіт окремої людини. Так, мати ліричного героя «Вибілювала світ, як полотно <.. > // Вже й голова в неситому вапні - // немов листок опалий у вогні» (Кичинський, 1988: 33), тобто займалася цим мікросвітом. Також варто відзначити й часовий аспект хронологічного опису, виявлений як безпосередньо через метафоричне позначення сивини (голова в вапні), так 
й опосередковано - через порівняння матері з листком опалим. Сусідство площин світу й часу відбувається навіть у межах одного рядка: «світ стоїь у задумі - в диму голова» (Кичинський, 1988: 39) (вони між собою не пов'язані причинно-наслідковими зв'язками, а просто наявні в межах двох метафор, перша з яких характеризує статичність довколишнього світу, а друга позначає сивину через колористичне зіставлення з димом).

Одиниця світ у значенні 'всесвіт, окрема частина всесвіту, земна куля, суспільство’ виявляє однокореневу природу з іменником світло («промениста енергія, що випромінюється яким-небудь тілом, сприймається зором і робить видимим навколишнє» (Великий тлумачний словник..., 2001: 1298]). Саме цю семантичну спільність А. Кичинський кладе в основу фразеологізму «Світ без світла - то вже несвіт» (Кичинський, 1982: 25), де іменник світло виявляє не лише означену вище фізичну ознаку, але й духовну (філософську), що позначає позитивність і конструктивність світу.

Нерозривність у межах макроконцепту «всесвіт» небесних і земних елементів маніфестується А. Кичинським через різноманітні природні процеси. Наприклад, у фрагменті «Йдуть у землю дощі, // йдуть у землю сніги. // небо в землю рікою впада голубою. // I беруться за руки усі береги - // і утворюють коло незриме собою» (Кичинський, 1988: 79) метафорична конструкція небо в землю рікою впада, що позначає означену нерозривність, конкретизується в препозиції виділеними реченнями, що через дублювання моделі акцентують на напрямку дії «з неба (репрезентанти - дощі й сніги) - у землю».

У П. Перебийноса метафоричні конструкції з елементом земля вказують на те, що ліричний герой тут мешкає, із землею пов'язане його життя: «А я із планети Земля» (Перебийніс, 1979: 10) (іменник планета позначає астрономічний статус Землі); «Iду // в задумі // по Землі» (дієслово іду сприймаємо в конотації «живу»); «Земля несе мене в просторі. // На розпашілому чолі // тріскочуть іскорками зорі» (Перебийніс, 1979: 9) (дієслівне словосполучення несе мене в просторі сприймаємо як часову ознаку проживання). Загалом написання з великої літери іменника Земля маркує ії як планету, і поет ототожнює себе з нею: «Несе галактика мене», «трасують полум'ям орбіти», «I я на схрещенні орбіт // зорю викрешую бентежно. // Згоряє соние, // як болід, // на тлі холодного Безмежжя» (Перебийніс, 1979: 9) 
(космічний простір, у якому переміщується герой-Земля, виявляється через лексичні елементи категорії «Всесвіт» - галактика, орбіти, зоря, сонце, болід, а також означальне словосполучення холодне Безмежжя, що позначає Всесвіт через якісний прикметник холодне як ознаку незвіданості й написання іменника Безмежжя з великої літери).

Відчуття єднання із землею є спільним в обох поетів. Так, А. Кичинський у цьому відчуває взагалі сутність справжнього життя: «Ляжу в траву лугову, // землю відчую живлющу, // очі від щастя заплющи, // видихну тихе “живу”...» (Кичинський, 1991: 55). Ознаки цієї реальності він маніфестує дієслівними словосполученнями землю відчую, очі від щзастя заплющу, де остання фраза позначає найвищу насолоду людини.

Образ землі не часто набуває в поета значення власне планети (часом це можна визначити лише за написанням з великої літери), хоча іiі значення - переважно концептуальне. Наприклад, у строфі «Ще й твої долоні, Земле, // та на них - $і$ дріб, і зерна // для птахів, // та густі мазутні плями, // та сліди від губ, та шрами // від цвяхів...» (Кичинський, 1991: 68) виділене нами словосполучення $є$ частиною розгорнутої метафоричної конструкції, що вказує на зіставлення землі $з$ живою істотою й виконує три смислових функції: 1) як власне людина (ознака - долоні); 2) як головний суб’єкт світобудови (ознаки - сліди оберігання природи); 3) як Боже творіння (ознаки Христа сліди й поцілунків, і шрамів від катування).

П. Перебийніс у поезії «Етюд з м’ячем» наводить аналогію Землі як планети, що в зручному для навчальної наочності масштабі виконана у формі глобуса, з круглим м'ячем. Певною мірою казкова ситуація описана поетом у вигляді гри, де «м'ячиком-глобусом граються двоє». Метафоричні зіставлення стосуються переважно польоту «капронової копії кулі земної», що «пливе небесами з долоні в долоню», «кружляє по смаглявій орбіті», і на ній «мигтять океани, моря, континенти», тобто виділені дієслова вказують на динаміку руху планети-м’яча. Коли ж політ припиняється («м'яч відкотився на сонячну стежку»), то зупиняється й час: «завмерли простори землі голубої. // В задумі спинилась планета бентежна...» (Перебийніс, 1990: 124) (виділені дієслова із семантикою зупинки, статики).

Натомість А. Кичинський частіше використовує образ землі власне як планети. Проте у фрагменті «Впасти б, Земле, // на крила 
грядущі твої! // Ген з Чумацького Шляху // завернувщи до отчого дому, // впасти б, Земле, мені молодому // та й на трави циілющі твої..." (Кичинський, 1979: 36) особисте звернення до землі й відповідний контекст інакше пояснюють написання цього іменника з великої літери - через його уособлене значення для ліричного героя. Це не лише планета (ознака - подання в одному ряду з таким же космонімом Чумацький Шлях), а місце розташування отчого дому, місце, де ростуть трави иілющі. Повторення моделі «впасти на... (традиційний додаток - ...груди)» зі значенням спорідненості автора з цим об'єктом саме й позначає такий статус Землі.

На відміну від космічного статусу планети, земля в значенні її поверхні, що маркується П. Перебийносом написанням з малої літери, має концептуальне значення для людини, оскільки позначає багато життєво важливих для неї ознак. Це зокрема:

- власне грунт («І земля - не земля. // Лиш тріски, // лиш кістки» (Перебийніс, 2011: 492));

- колір («Чорна ти, немов земля» (Перебийніс, 2011: 6), «Посинішали висоти. // Пожовтішала земля» (Перебийніс, 2011: 455));

- сільськогосподарський атрибут, що має й родинні ознаки («Ciє житня земля // тишу дня голубого - // і рушник простеля // від матусі до Бога» (Перебийніс, 2005: 143), «що ви навік єдині // у зоряній родині, // щзо ия земля свята // без вас тут сирота» (звернення до бабусі з дідусем) (Перебийніс, 2005: 62));

- концепт - елемент української ККС («Та є ота земля свята - // земля з Тарасової хати» (Перебийніс, 2011: 444));

- часова ознака життя («Йти мені недовго. // Лину за літами. // Від землі дорога // в небо завертає» (Перебийніс, 2011: 490)).

При цьому земля як поверхня планети часто протиставляється небу в опозиції «тілесне - духовне» («земне - небесне», «матеріальне ідеальне» тощо), а тому також певною мірою є елементом Всесвіту. Наприклад, у рядках «Вогники в небі. // Вогники на землі. // Всесвіт - як писанка» (Перебийніс, 2011: 400) вогники постають елементами всесвітньої писанки, а тому й небо, і земля (написання з малої літери характеризує їх рівноправність) входять до загального вселенського простору.

Темі космосу в П. Перебийноса присвячено численні метафори: «Ще на Марсі підошви не місять // бантастичні червоні піски. // Ще двадияте століття на Місяцьь// прокладає місточок хисткий. // Та чекає космічна дорога, // Шлях Чумацький від солі збілів» (Перебийніс, 
1990: 105). Серед елементів категорії «космос» - астроніми Mapc, Miсяць і сузір'я Чумацький Шлях, а також означальні словосполучення - власне космічна дорога й червоні піски, що характеризує виключно поверхню Марсу.

Обидва поети зв'язок земного й космічного світів виявляють у комплексі реального ландшафтного опису й астрального. В А. Кичинського - у межах опису: «Безвітряний вечір. Дорога осіння. // Небесна замріяність праху земного» (Кичинський, 2004: 107) (у виділеному метафоричному словосполученні поєднано обидва аспекти, що загалом виявляють ознаку статичності). У П. Перебийноса - у зіставленні з елементами сільського господарства. Зокрема, у поезії «Ми ходили з татом на баштан» автор асоціює баштан з незнайомою галактикою, де «розкотилися жовто-зелені глобуси кавунів», де «кружеляла земля», «кружеляли кавуни», і ті кавуни «могли б розлетітися в космосі, // якби не були прив'язані до землі // пересохлими пуповинами. // I кружеляли кавуни // з теплою планетою, // як тимчасові ї супутники» (Перебийніс, 1990: 68). Метафоричні конструкції з лексемою кавуни й інші виділені елементи формують ознаки космічного світу, однак тут наявна й тема прив'язаності до землі (якби не були прив'язані до землі), що є домінантою в поезіях автора.

\section{Висновки}

Отже, головними об'єктами концептосфери «природа» в поетичній мові П. Перебийноса й А. Кичинського визначено концепти-категорії «земля», «степ», «космос», «село», що взаємопов'язані в описах ландшафту, репрезентуючи реципієнтні й донорські елементи метафоричних й епітетних конструкцій. Вони переважно виявляють антропоморфні ознаки, що маніфестують авторські поетичні інтенції.

\section{ЛІТЕРАТУРА}

1. Великий тлумачний словник сучасної української мови / уклад. і голов. ред. В.Т. Бусел. Київ; Ірпінь: ВТФ «Перун», 2001. 1440 с. 2. Загнітко А. П. Сучасні типології концептів: когнітивний, лінгвокультурний, прагматичний аспекти. Науковий вісник Херсонського державного університету. Серія «Лінгвістика». Херсон: Вид-во ХДУ, 2010. Вип. ХІ. С. 33-46. 3. Кичинський А. В гості до мами. Вірші, поема. Київ: Веселка, 1991. 94 с. 4. Кичинський А. Дорога завдовжки в любов. Поезії. Київ: Молодь, 1988. 112 с. 5. Кичинський А. Землі зелена кров. Поезії. Київ: Молодь, 1982. 80 с. 6. Кичинський А. Світло трави. Вірші, поема. Сімферополь: Таврія. 1979. 64 с. 7. Кичинський А. І. Пролітаючи над листопадом: Поезіі. Херсон: Айлант, 2004. 128 с. 8. Максюта М. Є. «Хліборобський» поворот у світоглядній свідомості 
на порозі третього тисячоліття: «георгіки душі» для глобалізованого людства. Людина і культура в умовах глобалізацї: зб. наук. статей. Київ: Парапан, 2003. С. 145-155. 9. Мойсієнко А. Мова як світ світів. Поетика текстових структур. Умань, 2008. 280 с. 10. Павличко Д. Погляд з вічності. Світ поезій Петра Перебийноса. Перебийніс П. Цивілізація дерев. Київ: Укр. письм., 2011. С. 5-11. 11. Перебийніс П. Небо твоє і земля: Поезіі. Київ: Молодь, 1979. 112 с. 12. Перебийніс П. Пшеничний годинник. Київ: ВІК, 2005. 352 с. 13. Перебийніс П. Точний час: поезії. Київ: Рад. письм., 1990. 135 с. 14. Перебийніс П. Цивілізація дерев. Київ: Укр. письм., 2011. 392 с.

\section{REFERENCES}

1. Busel, V. T. (2003). Velykyi tlumachnyi slovnyk suchasnoi ukrainskoi movy. [A great explanatory dictionary of modern Ukrainian]. Kyiv: Perun [in Ukrainian]. 2. Zahnitko, A. P. (2010). Suchasni typolohii kontseptiv: kohnityvnyi, linhvokulturnyi, prahmatychnyi aspekty. [Modern typologies of concepts: cognitive, linguocultural, pragmatic aspects]. Naukovyi visnyk Khersonskoho derzhavnoho universytetu. Seriia "Linhvistyka» - Scientific Bulletin of Kherson State University. Linguistics Series, XI, 33-46 [in Ukrainian]. 3. Kychynskyi, A. (1991). Vhosti do mamy. [Visiting mother. Poems]. Kyiv: Veselka [in Ukrainian]. 4. Kychynskyi, A. (1988) Doroha zavdovzhky v liubov. [The road is long in love]. Poezii. Kyiv: Molod [in Ukrainian]. 5. Kychynskyi, A. (1982). Zemli zelena krov. [The Earth's green blood]. Poezii. Kyiv: Molod [in Ukrainian]. 6. Kychynskyi, A. (1979). Svitlo travy. [Light of grass]. Virshi, poema. Simferopol: Tavriia [in Ukrainian]. 7. Kychynskyi, A. I. (2004). Prolitaiuchy nad lystopadom: Poezii. [Flying over November: Poetry.]. Kherson: Ailant [in Ukrainian]. 8. Maksiuta, M. Ye. (2003) «Khliborobskyi» povorot u svitohliadnii svidomosti na porozi tretoho tysiacholittia: "heorhiky dushi» dlia hlobalizovanoho liudstva. ["The bakery" turn in world-view on the threshold of the third millennium: "soul of George" for globalized humanity]. Liudyna i kultura v umovakh hlobalizatsii. Kyiv: Parapan [in Ukrainian]. 9. Moisiienko, A. (2008). Mova yak svit svitiv. [Language as a world of worlds]. Poetyka tekstovykh struktur. Uman [in Ukrainian]. 10. Pavlychko, D. (2011). Pohliad z vichnosti.. Svit poezii Petra Perebyinosa [A look from eternity. The World of Poetry by Peter Perebynos]. Perebyinis P. Tsyvilizatsiia derev - Perebynis P. Civilization of trees, (pp. 5-11). Kyiv: Ukr. pysm. [in Ukrainian]. 11. Perebyinis, P. (1979). Nebo tvoie i zemlia: Poezii. [Your heaven and earth: Poetry]. Kyiv: Molod [in Ukrainian]. 12. Perebyinis, P. (2005). Pshenychnyi hodynnyk. [Wheat clock]. Kyiv: VIK [in Ukrainian]. 13. Perebyinis, P. (1990). Tochnyi chas: poezii. [The exact time: poetry]. Kyiv : Rad. pysm. [in Ukrainian]. 14. Perebyinis, P. (2011). Tsyvilizatsiia derev. [The civilization of trees]. Kyiv: Ukr. pysm. [in Ukrainian].

Бєлінсвка Валерія Євгенівна - аспірантка кафедри української мови, Харківський національний педагогічний університет імені Г. С. Сковороди; вул. Валентинівська, 2, м. Харків, 61168, Україна.

Tel.: +38-095-517-58-03

E-mail: valerybelinska@gmail.com

https://orcid.org/0000-0002-7276-0426

Belinska Valeriia - Postgraduate Student, Ukrainian Language Department, H. S. Skovoroda Kharkiv National Pedagogical University; Valentynivska Str. 2, Kharkiv, 61168, Ukraine. 